\title{
Effect of age and gender on sweat lactate and ammonia concentrations during exercise in the heat
}

F. Meyer ${ }^{1}$, O. Laitano ${ }^{1}$, O. Bar-Or' ${ }^{2}$, D. McDougall ${ }^{2}$ and G.J.F. Heigenhauser ${ }^{2}$

\author{
'Laboratório de Pesquisa do Exercício, Escola de Educação Física, \\ Universidade Federal do Rio Grande do Sul, Porto Alegre, RS, Brasil \\ ${ }^{2}$ Children's Exercise and Nutrition Centre, Department of Pediatrics, \\ Department of Physical Education, Department of Medical Sciences, \\ McMaster University, Hamilton, Ontario, Canada
}

Correspondence
O. Laitano
Laboratório de Pesquisa do Exercício
Escola de Educação Física, UFRGS
Rua Felizardo, 750
$90690-200$ Porto Alegre, RS
Brasil
E-mail: lionello@terra.com.br
Research supported by a
grant from the Gatorade Sports
Science Institute. F. Meyer was
the recipient of a fellowship
from CNPq.
... . . . . . . . . . . . . . . . . . .

Received November 10, 2005 Accepted July 12, 2006

\section{Abstract}

The dependence of sweat composition and acidity on sweating rate (SR) suggests that the lower SR in children compared to adults may be accompanied by a higher level of sweat lactate $\left(\mathrm{Lac}^{-}\right)$and ammonia $\left(\mathrm{NH}_{3}\right)$ and a lower sweat $\mathrm{pH}$. Four groups (15 girls, 18 boys, 8 women, 8 men) cycled in the heat $\left(42^{\circ} \mathrm{C}, 20 \%\right.$ relative humidity) at $50 \%$ $\mathrm{VO}_{2 \max }$ for two 20-min bouts with a 10-min rest before bout 1 and between bouts. Sweat was collected into plastic bags attached to the subject's lower back. During bout 1, sweat from girls and boys had higher Lac $^{-}$concentrations $(23.6 \pm 1.2$ and $21.2 \pm 1.7 \mathrm{mM} ; \mathrm{P}<0.05)$ than sweat from women and men $(18.2 \pm 1.9$ and $14.8 \pm 1.6 \mathrm{mM}$, respectively), but $\mathrm{Lac}^{-}$was weakly associated with $\mathrm{SR}(\mathrm{P}>0.05 ; \mathrm{r}=$ -0.27). Sweat $\mathrm{Lac}^{-}$concentration dropped during exercise bout 2 , reaching similar levels among all groups (overall mean $=13.7 \pm 0.4$ $\mathrm{mM}$ ). Children had a higher sweat $\mathrm{NH}_{3}$ than adults during bout 1 (girls $=4.2 \pm 0.4$, boys $=4.6 \pm 0.6$, women $=2.7 \pm 0.2$, and men $=3.0 \pm 0.2$ $\mathrm{mM} ; \mathrm{P}<0.05)$. This difference persisted through bout 2 only in females. On average, children's sweat $\mathrm{pH}$ was lower than that of adults $($ mean \pm SEM, girls $=5.4 \pm 0.2$, boys $=5.0 \pm 0.1$, women $=6.2 \pm 0.5$, and men $=6.2 \pm 0.4$ for bout 1 , and girls $=5.4 \pm 0.2$, boys $=6.5 \pm 0.5$, women $=5.2 \pm 0.2$, and men $=6.9 \pm 0.4$ for bout 2 ). This may have favored $\mathrm{NH}_{3}$ transport from plasma to sweat as accounted for by a significant correlation between sweat $\mathrm{NH}_{3}$ and $\mathrm{H}^{+}(\mathrm{r}=0.56)$. Blood $\mathrm{pH}$ increased from rest (mean $\pm \mathrm{SEM} ; 7.3 \pm 0.02$ ) to the end of exercise $(7.4 \pm 0.01)$ without differences among groups. These results, however, are representative of sweat induced by moderate exercise in the absence of acidosis.

\section{Introduction}

During prolonged exercise in the heat, two major solutes excreted in sweat are lactate $\left(\mathrm{Lac}^{-}\right)$and ammonia $\left(\mathrm{NH}_{3}\right)$, whose re-
Key words

- Sweat $\mathrm{pH}$

- Electrolytes

- Ammonia

- Lactate

................. 
from the sweat gland itself or by diffusion from plasma $(1,5,6)$.

The widely reported variability in sweat $\mathrm{Lac}^{-}$and $\mathrm{NH}_{3}$ may be accounted for by their dependence on factors such as sweating rate (SR), sweat acidity, and the transport of other ions in the duct of the sweat gland. These factors may in turn determine the concentration of a person's sweat $\mathrm{Lac}^{-}$and $\mathrm{NH}_{3}$. For example, $\mathrm{SR}$ was shown to inversely correlate with sweat $\mathrm{Lac}^{-}(7,8)$. Lamont (8) detected very high sweat Lac(43-100 $\mathrm{mM}$ ) in women and suggested that this reflects women's lower SR. Controlled studies found no gender differences in SR in either adults (9) or children (10). However, males had a higher SR when corrected for surface area and compared with females (11). Thus, based on SR alone, it is unlikely that sweat Lac- would be different between genders. Because SR has been shown to increase with maturation, we hypothesized that sweat Lac- should be higher in children than in adults. Indeed, sweat $\mathrm{Lac}^{-}$has already been demonstrated to be higher in prepubescent than in late-pubescent boys at the first 20 min of moderate exercise $\left(50 \% \mathrm{VO}_{2 \max }\right)$ (7). It is not known whether this difference persists through adulthood.

Much less is known about inter-individual differences in sweat $\mathrm{NH}_{3}$ during exercise. $\mathrm{NH}_{3}$ transport between water compartments depends on the $\mathrm{pH}$ gradient, moving towards the lower $\mathrm{pH}$. It has been shown $(1,12)$ that sweat $\mathrm{pH}$ is lower (5 to 7) than blood $\mathrm{pH}$.
Whether sweat $\mathrm{pH}$ differs between children and adults during exercise has not yet been demonstrated. One might predict that sweat $\mathrm{pH}$ would be lower in children than in adults for two reasons: the expected higher sweat Lac in children and the increase of $\mathrm{pH}$ with SR $(13,14)$. One possible way to prevent very low levels of sweat $\mathrm{pH}$ is to increase its $\mathrm{NH}_{3}$ content. Therefore, we hypothesized that a lower sweat $\mathrm{pH}$ in children would be accompanied by a higher sweat $\mathrm{NH}_{3}$.

The main purpose of the present study was to compare sweat $\mathrm{Lac}^{-}$and $\mathrm{NH}_{3}$ and their respective losses among four groups (girls, boys, women, and men) that exercised intermittently $(1 \mathrm{~h})$ at the same relative intensity $\left(50 \% \mathrm{VO}_{2 \max }\right)$ and under the same environmental conditions.

\section{Subjects and Methods}

\section{Subjects}

Forty-nine subjects ( 15 girls, 8 women, 18 boys, and 8 men) were included in the study and signed an informed consent term. Their physical characteristics are shown in Table 1. Seventeen children out of a total of 33 were prepubescent and 16 ( 8 girl and 8 boys) were at the beginning or in the middle of puberty. All subjects were healthy as determined by a medical interview and a physical examination. Experiments took place during the late fall and winter in Ontario, Canada, suggesting that subjects were not acclimatized to the heat.

Table 1. Physical and physiological characteristics of the subjects.

\begin{tabular}{lcccc}
\hline & Girls $(\mathrm{N}=15)$ & Boys $(\mathrm{N}=18)$ & Women $(\mathrm{N}=8)$ & Men $(\mathrm{N}=8)$ \\
\hline Age $^{*}$ (years) & $10.5 \pm 1.8$ & $9.9 \pm 1.5$ & $21.5 \pm 0.7$ & $23.4 \pm 2.0$ \\
Height $^{*}(\mathrm{~cm})$ & $148.6 \pm 12$ & $143.9 \pm 10.4$ & $166.4 \pm 4$ & $178.4 \pm 8.2$ \\
Weight $^{*}(\mathrm{~kg})$ & $40.2 \pm 8.4$ & $35.8 \pm 7.8$ & $60.5 \pm 7.2$ & $76.3 \pm 7.3$ \\
Surface area $^{*}\left(\mathrm{~m}^{2}\right)$ & $1.29 \pm 0.18$ & $1.22 \pm 0.16$ & $1.66 \pm 0.10$ & $1.83 \pm 0.11$ \\
$\Sigma 4$ Skinfold $(\mathrm{mm})$ & $36.8 \pm 11.4$ & $29.6 \pm 11.4$ & $39.4 \pm 13.0$ & $37.8 \pm 18.4$ \\
Peak VO & $40.4 \pm 4.4$ & $47.6 \pm 5.8$ & $42.3 \pm 4.1$ & $46.6 \pm 4.2$ \\
\hline
\end{tabular}

Data are reported as mean \pm SD.

${ }^{*} \mathrm{P}<0.05$ for girls $v s$ women and boys vs men (ANOVA). 
The McMaster University Ethics Committee approved this study.

\section{Procedures and protocols}

Prior to the experimental session, subjects came to the laboratory for anthropometric and peak $\mathrm{VO}_{2}$ tests. Weight and height were measured, and body surface area (in $\mathrm{m}^{2}$ ) was calculated by the formula of DuBois and DuBois (15) (body surface area = $0.20247 \mathrm{x}$ height $(\mathrm{m})^{0.725} \mathrm{x}$ body mass $(\mathrm{kg})^{0.425}$. Adiposity was calculated by summing 4 skinfolds (triceps, biceps, subscapular, and suprailiac) measured in triplicate with a Harpenden caliper. Peak $\mathrm{VO}_{2}$ was assessed by adopting a continuous progressive (2-min stages) protocol on a cycle ergometer, at a constant cadence of $50 \mathrm{rpm}$, in a thermoneutral environment. The test was terminated upon subject's volitional exhaustion or when the target cadence could not be maintained. $\mathrm{VO}_{2}$ was measured with an opencircuit spirometer with respiratory gases analyzed through an automated system (Beckman-Horizon Metabolic Cart, Anaheim, CA, USA).

On the day of the in-chamber trial, subjects were advised to come to the laboratory having abstained from drinking alcohol for $48 \mathrm{~h}$, caffeine for $8 \mathrm{~h}$, and from exercising in the previous $2 \mathrm{~h}$. Subjects were encouraged to drink large volumes of water on this day and, upon arrival in the laboratory, they were given 150-250 mL of water to reduce the likelihood of hypohydration. Before entering the chamber $\left(40-42^{\circ} \mathrm{C}\right.$ and $18-20 \%$ relative humidity), subjects voided and dressed in shorts and sports shoes, plus bikini tops for females.

In the chamber, subjects cycled (Monark, Varberg, Sweden) for two 20-min bouts at $50 \%$ of their predetermined peak $\mathrm{VO}_{2}$, with a 10-min rest before bout 1 and between bouts. $\mathrm{VO}_{2}$ was measured in the middle of bout 2. Heart rate (Sport Tester PE3000 system, Kempele, Finland) and rectal tem- perature (YSI 400 series, Yellow Springs, $\mathrm{OH}$, USA) were measured continuously. Subjects were kept euhydrated by drinking cool $\left(8-12^{\circ} \mathrm{C}\right)$ water throughout the session. Hydration state was checked by weighing subjects before and after bout 1 , and at the end of the session using a Mott electroscale LC2424, $\pm 20 \mathrm{~g}$ accuracy (Brantford, Ontario, Canada).

\section{Sampling and analysis of sweat and blood}

To guarantee enough volume, sweat was collected into two plastic bags (one in each side) attached to the subjects' lower back as previously described $(7,10)$. The format of the plastic bag was such that the skin area covered was equivalent in children and adults. Once collected, the sample was stored in microtubes and frozen $\left(-4^{\circ} \mathrm{C}\right)$ until biochemical analysis. A separate sample was frozen at $-70^{\circ} \mathrm{C}$ for the $\mathrm{pH}$ and $\mathrm{NH}_{3}$ determination.

Sweat $\mathrm{Lac}^{-}$was determined using the Yellow Springs Instrument analyzer (model 23L; Yellow Springs, $\mathrm{OH}$, USA), $\mathrm{NH}_{3}$ was determined by spectrophotometry using a colorimetric assay (Sigma 70-UV, St. Louis, MO, USA), and osmolality by freezing point depression (Model 3M0, Needham Heights, MA, USA). Sweat $\mathrm{Na}^{+}$and $\mathrm{K}^{+}$were measured using ion selective electrodes (Kodak Ektachem Analyzer 700XR, Rochester, NY, USA) and $\mathrm{Cl}^{-}$was measured with a BuchlerCotlover chloridometer (Kansas City, MO, USA). Sweat $\mathrm{pH}$ was determined using Radiometer $\mathrm{pH}-(\mathrm{g} 2040 \mathrm{c})$ and reference (K4040) electrodes coupled to a Radiometer PHu62 pH meter (Hamilton, Ontario, Canada).

Blood samples were drawn at rest after the subjects had rested for $15 \mathrm{~min}$ (seated) in the thermoneutral room, and during the last minute of bout 2 while they were still cycling. To facilitate blood collection without stasis, subjects kept their hands in warm water $\left(40-45^{\circ} \mathrm{C}\right)$ for $15 \mathrm{~min}$ prior to collec- 
tion. Using a 21-gauge butterfly, blood was collected $(6 \mathrm{~mL})$ from a vein of the dorsum of the hand, without stasis, into a blood gas syringe and into two vacutainers containing lithium heparin and EDTA. The blood collected anaerobically into a syringe was freed from air bubbles, sealed, and kept on ice until determination (within $1 \mathrm{~h}$ ) of blood gases, $\mathrm{HCO}_{3}$, and $\mathrm{pH}$ (AVL 995/Blood Gas Analyzer with $\mathrm{H}^{+}, \mathrm{O}_{2}$ and $\mathrm{CO}_{2}$ electrodes; Roswel, GA, USA). Blood $\mathrm{Lac}^{-}$was analyzed immediately (model 23L, Yellow Springs Instruments) in the sample from one of the vacutainers (lithium heparin). Blood was then centrifuged and the plasma was kept on ice for later analysis. Plasma electrolyte concentrations were measured using ion selective electrodes (Kodak Ektachem Analyzer 700XR), protein was measured by refractometry, and osmolality was measured by freezing point depression (model 3MO). The blood sample collected into EDTA vacutainers was used for hematocrit and hemoglobin determination (Coulter-Counter, Model S-plus STKR; Miami, FL, USA).

\section{Calculations}

Sweating rate was calculated from the differences in nude body weight obtained before and immediately after the experiment, corrected for fluid intake, respiratory water loss (16), and urine volume and corrected for surface area $\left(\mathrm{m}^{2}\right)$ and time (min). Sweat lactate and $\mathrm{NH}_{3}$ losses were calculated by multiplying the volume of total body sweat by its respective concentration. Hydration level was calculated by the change in body weight and expressed as percent initial body weight, corrected for urine output and change in clothes weight. Percent changes in plasma volume ( $\% \Delta \mathrm{PV})$ and red blood cell volume $(\% \Delta \mathrm{RBC})$ were calculated from changes in hemoglobin and hematocrit (17). Exercise blood $\mathrm{Lac}^{-}$was corrected for $\% \Delta \mathrm{PV}$. Sweat $\mathrm{pH}$ was converted to the equivalent free hydrogen ion $\left(\mathrm{H}^{+}\right)$.
Plasma and sweat strong ion difference (SID) were calculated as $\mathrm{Na}^{+}+\mathrm{K}^{+}-\mathrm{Cl}^{-}-\mathrm{Lac}^{-}$and $\mathrm{Na}^{+}+\mathrm{K}^{+}+\mathrm{NH}_{3}-\mathrm{Cl}^{-}-\mathrm{Lac}^{-}$, respectively.

\section{Statistical analysis}

Within genders, prepubescent and pubescent subjects were found to be similar with respect to all sweat and blood parameters, as determined by two-way analysis of variance (ANOVA). The children were therefore pooled into two groups: boys and girls. ANOVA was used to compare children $v s$ adults and females vs males. Two-way ANOVA was used to examine changes with time (e.g., bout 1 vs bout 2). Statistical significance was considered when $\mathrm{P}<0.05$. Data are reported as means \pm SEM.

\section{Results}

\section{Physiological responses}

The mean increase in rectal temperature $\left({ }^{\circ} \mathrm{C}\right)$ from rest to the end of bout 2 did not differ among groups: $0.90 \pm 0.08$ (girls), $0.83 \pm 0.08$ (boys), $0.75 \pm 0.11$ (women), and $0.81 \pm 0.07$ (men). Heart rate (bpm) at the end of bout 2 was similar among groups: $165 \pm 4$ (girls), $162 \pm 7$ (boys), $162 \pm 6$ (women), $159 \pm 8$ (men). By the end of bout 2 , most subjects maintained their hydration levels within $1 \%$ of initial body weight (range $=-0.6$ to $0.8 \%)$. The mean \pm SEM percent change in body weight per group was $0.11 \pm$ 0.09 (girls), $0.01 \pm 0.11$ (boys), $-0.09 \pm 0.3$ (women), $-0.19 \pm 0.02$ (men).

\section{Sweat composition}

Children had 25\% higher sweat Lac- than their counterparts after bout $1(\mathrm{P}<0.05$; Table 2). In each group there was a drop in sweat $\mathrm{Lac}^{-}$from bout 1 to bout 2, and all groups ended the session with similar values (overall mean $\pm \mathrm{SEM}=13.7 \pm 0.4 \mathrm{mM}$ ) . Within the maturational group, there was no 
gender difference in sweat $\mathrm{Lac}^{-}$. Mean sweat $\mathrm{NH}_{3}$ after bout 1 was $66 \%$ higher in children than in adults. Although sweat $\mathrm{NH}_{3}$ did not change significantly with time in any group, opposite trends among groups resulted in men having similar values to boys but higher than women (Table 2). The total sweat losses of $\mathrm{Lac}^{-}$were higher in adults than in children, but similar among groups when corrected for kg body mass (Table 3). A similar trend was found for total $\mathrm{NH}_{3}$. Men had a higher sweat $\mathrm{Na}^{+}$and $\mathrm{Cl}^{-}$compared to the other groups. Men's sweat $\mathrm{Cl}^{-}$increased from bout 1 to bout 2 (Table 2). Girls and boys had higher $\mathrm{K}^{+}$than their adult counterparts in bout 1. Overall, sweat SID was similar among groups with one exception: at bout 2, it was higher in boys than in men. Sweat $\mathrm{H}^{+}$was lower in men compared to boys during bouts 1 and 2, and compared to women during bout 2 (Table 4). The lower sweat $\mathrm{H}^{+}$of women compared with girls was close to being statistically significant $(\mathrm{P}=0.07$ in bout 1 , and $\mathrm{P}=0.06$ in bout 2 ). Sweat $\mathrm{pH}$ during both bouts was lower in girls and boys compared to their adult counterparts. The respective means \pm SEM were $5.4 \pm 0.2$ (girls), $5.0 \pm 0.1$ (boys), $6.2 \pm 0.5$ (women), and $6.2 \pm 0.4$ (men) for bout 1 , and $5.4 \pm 0.2$ (girls), $6.5 \pm 0.5$ (boys), $5.2 \pm 0.2$ (women), and $6.9 \pm 0.4$ (men) for bout 2 .

While sweat osmolality decreased in boys and girls $(\mathrm{P}<0.05)$, it did not change in men and women (Table 4). SR was consistently lower in girls and boys compared to their respective adult group (Table 4).

\section{Blood results}

Blood $\mathrm{pH}$ at rest was similar among groups, while at the end of exercise it was higher in girls than in women (Table 5). However, the magnitude of the changes in blood $\mathrm{pH}, \mathrm{HCO}_{3}{ }^{-}$, and $\mathrm{PCO}_{2}$ was similar among the four groups (Table 5). Overall there was an increase in blood $\mathrm{pH}$ and a decrease in $\mathrm{HCO}_{3}{ }^{-}$and $\mathrm{PCO}_{2}$. When changes within groups were analyzed, significant differences $(\mathrm{P}<0.05)$ were found in all groups for blood $\mathrm{PCO}_{2}$, but not for $\mathrm{pH}$ or $\mathrm{HCO}_{3}{ }^{-}$ (Table 5). While blood $\mathrm{Lac}^{-}$increased in men, it decreased in boys and did not change in the female groups.

Plasma osmolality and RBC volume did not change from rest to the end of the exercise session. There was a decrease in PV and an increase in plasma proteins in all groups, with these changes being significantly greater in adults $(\mathrm{P}<0.05$; Table 6$)$. There was no change in plasma $\mathrm{Na}^{+}$or $\mathrm{Cl}^{-}$from rest to the end of the exercise session in any of the groups, while plasma $\mathrm{K}^{+}$increased on average by $12 \%$ in boys to $18 \%$ in men. In all groups, plasma SID did not change from rest to the end of bout 2 , with values (mean \pm SEM) of $37.7 \pm$ 0.48 and $37.6 \pm 0.5 \mathrm{mM}$, respectively.

Table 2. Sweat lactate $\left(\mathrm{Lac}^{-}\right)$, ammonia $\left(\mathrm{NH}_{3}\right)$, sodium $\left(\mathrm{Na}^{+}\right)$, chloride $\left(\mathrm{Cl}^{-}\right)$, and potassium $\left(\mathrm{K}^{+}\right)$concentrations.

\begin{tabular}{|c|c|c|c|c|c|c|c|c|c|c|}
\hline & \multicolumn{2}{|c|}{$\mathrm{Lac}^{-}(\mathrm{mM})$} & \multicolumn{2}{|c|}{$\mathrm{NH}_{3}(\mathrm{mM})$} & \multicolumn{2}{|c|}{$\mathrm{Na}^{+}(\mathrm{mM})$} & \multicolumn{2}{|c|}{$\mathrm{Cl}^{-}(\mathrm{mM})$} & \multicolumn{2}{|c|}{$\mathrm{K}^{+}(\mathrm{mM})$} \\
\hline & Bout 1 & Bout 2 & Bout 1 & Bout 2 & Bout 1 & Bout 2 & Bout 1 & Bout 2 & Bout 1 & Bout 2 \\
\hline Girls & $24.0 \pm 1.0^{\#}$ & $14.6 \pm 0.5$ & $4.4 \pm 0.3$ & $3.9 \pm 0.2$ & $26.0 \pm 3.0$ & $27.0 \pm 2.5$ & $12.0 \pm 1.0$ & $19.0 \pm 1.3$ & $17.0 \pm 1.0^{\#}$ & $12.0 \pm 0.4$ \\
\hline Boys & $22.0 \pm 1.7^{*}$ & $14.0 \pm 0.4$ & $4.7 \pm 0.4$ & $4.3 \pm 0.2$ & $33.0 \pm 2.2$ & $38.6 \pm 2.0^{*}$ & $22.0 \pm 1.8$ & $25.0 \pm 2.9^{*}$ & $14.0 \pm 1.0^{*}$ & $10.0 \pm 0.1^{*}$ \\
\hline Women & $17.4 \pm 1.4$ & $11.9 \pm 0.3$ & $2.8 \pm 0.1$ & $2.5 \pm 0.1$ & $32.0 \pm 1.8^{*}$ & $38.5 \pm 0.5^{\star}$ & $23.5 \pm 1.2$ & $30.0 \pm 2.5$ & $9.0 \pm 0.9^{*}$ & $8.0 \pm 0.1$ \\
\hline Men & $15.4 \pm 0.9$ & $12.7 \pm 1.2$ & $3.0 \pm 0.1$ & $3.9 \pm 0.3$ & $50.0 \pm 8.0$ & $61.0 \pm 10$ & $40.0 \pm 7.5$ & $57.0 \pm 6.8$ & $6.0 \pm 0.4$ & $5.5 \pm 0.6$ \\
\hline
\end{tabular}

Data are reported as means \pm SEM.

${ }^{*} \mathrm{P}<0.05$ compared to men (within bouts) (ANOVA). $\mathrm{P} P<0.05$ compared to women (within bouts) (ANOVA). Lac- decreased from bout 1 to bout 2 in all groups $\left(\mathrm{P}<0.05\right.$, two-way ANOVA). $\mathrm{Cl}^{-}$increased in men and $\mathrm{K}^{+}$decreased in girls and boys from bout 1 to bout $2(\mathrm{P}<0.05$, two-way ANOVA). 
Table 3. Total sweat lactate and ammonia losses throughout the whole exercise session (bout $1+$ bout 2).

\begin{tabular}{lrccc}
\hline & Lactate $(\mathrm{mM})$ & Lactate $\left(\mathrm{mM} \mathrm{kg}^{-1} \mathrm{~h}^{-1}\right)$ & Ammonia $(\mathrm{mM})$ & Ammonia $\left(\mathrm{mM} \mathrm{kg}^{-1} \mathrm{~h}^{-1}\right)$ \\
\hline Girls & $5.45 \pm 0.94^{*}$ & $0.13 \pm 0.02$ & $1.11 \pm 0.17$ & $0.026 \pm 0.003$ \\
Boys & $4.83 \pm 0.54^{*}$ & $0.15 \pm 0.02$ & $1.33 \pm 0.14^{*}$ & $0.022 \pm 0.004$ \\
Women & $9.22 \pm 1.36$ & $0.15 \pm 0.02$ & $1.35 \pm 0.17$ & $0.037 \pm 0.002$ \\
Men & $11.40 \pm 2.30$ & $0.14 \pm 0.03$ & $2.35 \pm 0.46$ & $0.032 \pm 0.006$
\end{tabular}

Data are reported as mean \pm SD. Values are also corrected for body weight $(\mathrm{kg})$ and time $(\mathrm{h})$. ${ }^{*} \mathrm{P}<0.05$ compared to the respective adult group (ANOVA).

Table 4. Sweat hydrogen $\left(\mathrm{H}^{+}\right)$, strong ion difference (SID), osmolality, and sweating rate (SR).

\begin{tabular}{|c|c|c|c|c|c|c|c|c|}
\hline & \multicolumn{2}{|c|}{$\mathrm{H}^{+}(\mathrm{mM})$} & \multicolumn{2}{|c|}{ SID (mM) } & \multicolumn{2}{|c|}{ Osmolality (mOsm/kg) } & \multicolumn{2}{|c|}{$\mathrm{SR}\left(\mathrm{mL} \mathrm{m}^{2} \mathrm{~min}^{-1}\right)$} \\
\hline & Bout 1 & Bout 2 & Bout 1 & Bout 2 & Bout 1 & Bout 2 & Bout 1 & Bout 2 \\
\hline Girls & $8.0 \pm 3.0$ & $10.0 \pm 1.0$ & $9.8 \pm 4.0$ & $9.6 \pm 3.0$ & $119.0 \pm 3.2$ & $99.0 \pm 3.0$ & $2.8 \pm 0.7^{\#}$ & $4.2 \pm 0.6^{\#}$ \\
\hline Boys & $15.0 \pm 3.2$ & $13.0 \pm 2.3$ & $9.7 \pm 3.0$ & $14.0 \pm 2.0^{*}$ & $128.0 \pm 11.8$ & $118.0 \pm 7.4$ & $3.0 \pm 0.1^{*}$ & $4.7 \pm 0.02^{*}$ \\
\hline Women & $4.0 \pm 1.2$ & $3.8 \pm 1.4$ & $4.0 \pm 1.7$ & $4.3 \pm 1.8$ & $93.0 \pm 3.4^{*}$ & $105.0 \pm 6.2$ & $6.2 \pm 0.8$ & $6.4 \pm 0.8$ \\
\hline Men & $3.0 \pm 1.2$ & $2.5 \pm 1.0$ & $4.2 \pm 1.6$ & $1.2 \pm 8.0$ & $133.0 \pm 21.0$ & $141.0 \pm 15.3$ & $6.5 \pm 0.7$ & $8.0 \pm 0.7$ \\
\hline
\end{tabular}

Data are reported as mean \pm SEM.

${ }^{*} \mathrm{P}<0.05$ compared to men (within bouts) (ANOVA). \#P $<0.05$ compared to women (within bouts) (ANOVA). Osmolality decreased from bout 1 to bout 2 in girls and boys $(P<0.05$, two-way ANOVA).

Table 5. Blood pH, $\mathrm{HCO}_{3}{ }^{-}, \mathrm{PCO}_{2}$, and lactate ( $\left.\mathrm{Lac}^{-}\right)$at rest and at the end of the whole exercise session.

\begin{tabular}{|c|c|c|c|c|c|c|c|c|}
\hline & \multicolumn{2}{|c|}{$\mathrm{pH}$} & \multicolumn{2}{|c|}{$\mathrm{HCO}_{3}^{-}(\mathrm{mM})$} & \multicolumn{2}{|c|}{$\mathrm{PCO}_{2}(\mathrm{mmHg})$} & \multicolumn{2}{|c|}{$\mathrm{Lac}^{-}(\mathrm{mM})$} \\
\hline & Rest & Exercise & Rest & Exercise & Rest & Exercise & Rest & Exercise \\
\hline Girls & $7.33 \pm 0.02$ & $7.41 \pm 0.01^{*}$ & $27.0 \pm 0.6$ & $23.7 \pm 0.4^{*}$ & $51.6 \pm 1.9$ & $38.3 \pm 1.0^{*}$ & $0.7 \pm 0.1$ & $1.1 \pm 0.2$ \\
\hline Boys & $7.31 \pm 0.02$ & $7.40 \pm 0.01^{*}$ & $25.3 \pm 0.6$ & $24.8 \pm 0.3$ & $51.6 \pm 1.9$ & $41.1 \pm 0.7^{*}$ & $1.0 \pm 0.1$ & $0.8 \pm 0.1^{*}$ \\
\hline Women & $7.32 \pm 0.03$ & $7.35 \pm 0.02$ & $25.5 \pm 1.0$ & $23.8 \pm 1.0$ & $49.0 \pm 3.3$ & $41.5 \pm 3.2^{*}$ & $1.1 \pm 0.2$ & $1.4 \pm 0.2$ \\
\hline Men & $7.30 \pm 0.02$ & $7.36 \pm 0.02$ & $26.0 \pm 0.4$ & $24.3 \pm 0.5^{*}$ & $58.3 \pm 2.2$ & $43.9 \pm 1.6^{*}$ & $1.0 \pm 0.1$ & $1.8 \pm 0.3^{*+}$ \\
\hline
\end{tabular}

Data are reported as mean \pm SEM.

${ }^{*} \mathrm{P}<0.05$ compared to the respective resting values (two-way ANOVA); ${ }^{+P}<0.05$ compared to boys (ANOVA).

Table 6. Changes in plasma volume $(\Delta \mathrm{PV})$, red blood cells $(\triangle \mathrm{RBC})$, plasma protein ( $\triangle$ Protein), and osmolality ( $\Delta$ Osmolality) from rest to the end of exercise.

\begin{tabular}{lcccc}
\hline & \multicolumn{1}{c}{$\Delta \mathrm{PV}^{*}$} & $\Delta \mathrm{RBC}$ & $\Delta$ Protein $^{*}$ & $\Delta$ Osmolality \\
\hline Girls & $-3.6 \pm 1.4 \%^{+}$ & $0.08 \pm 0.5 \%$ & $4.62 \pm 0.9 \%^{+}$ & $0.09 \pm 0.6 \%$ \\
Boys & $-2.3 \pm 0.4 \%^{+}$ & $0.32 \pm 0.4 \%$ & $2.15 \pm 1.0 \%^{+}$ & $0.62 \pm 0.8 \%$ \\
Women & $-8.8 \pm 0.7 \%$ & $-1.25 \pm 0.9 \%$ & $9.22 \pm 1.4 \%$ & $0.95 \pm 0.6 \%$ \\
Men & $-8.6 \pm 2.0 \%$ & $-0.09 \pm 0.4 \%$ & $9.97 \pm 1.2 \%$ & $0.94 \pm 0.6 \%$
\end{tabular}

Data are reported in percent as means \pm SEM.

${ }^{*}$ Significant differences within each group $\left(P<0.05\right.$, ANOVA); ${ }^{+} P<0.05$ compared to the respective adult group (ANOVA). 


\section{Discussion}

The main purpose of the present study was to compare sweat $\mathrm{Lac}^{-}$and $\mathrm{NH}_{3}$, and their respective losses, between children and adults of both genders during one hour of intermittent exercise $\left(50 \%\right.$ peak $\mathrm{VO}_{2}$ ) in the heat. Girls and boys had a higher sweat $\mathrm{Lac}^{-}$and $\mathrm{NH}_{3}$ compared to their adult counterparts within 20 min of the beginning of exercise. Thereafter, this difference persisted in females for $\mathrm{NH}_{3}$ only. During this later stage of the session, men had higher sweat $\mathrm{NH}_{3}$ than women. This was the only gender difference found within age groups. The total sweat $\mathrm{Lac}^{-}$and $\mathrm{NH}_{3}$ losses, corrected per kg body mass, were similar among groups. To our knowledge, this was the first study that compared the four groups under the same conditions.

The overall sweat Lac of the boys (16.6 $\mathrm{mM})$ and men $(15.1 \mathrm{mM})$ in the present study agrees with those reported for boys (7) and men $(6,11,18)$ performing similar exercise protocols. The mean sweat $\mathrm{Lac}^{-}$of women $(14.3 \mathrm{mM})$ in the present study, however, was much lower than that of sedentary $(100 \mathrm{mM})$ or fit $(43 \mathrm{mM})$ women $(8)$. The method of collecting sweat (plastic bags vs whole body washdown) and the exercise intensity (50 vs $70 \% \mathrm{VO}_{2 \max }$ ) may have accounted for the difference. Although sweat collected with bags represents only one site of the body, it is a reliable (19) method and involves the least contamination (20). Unless the investigator is very familiar with the procedures, the whole-body washdown is prone to errors and, whenever used, its reliability should be reported (21-23).

Sweat $\mathrm{Lac}^{-}$at the beginning of exercise has been found to be higher in prepubertal than in adolescent boys (7). Green et al. (11) found that males have higher sweat lactate than females. Our findings were that, at this early stage of sweating, boys have a higher sweat $\mathrm{Lac}^{-}$than men and that corresponding differences exist in females. The present study is the first to compare sweat $\mathrm{Lac}^{-}$ among children and adults of both genders.

Although children's sweat Lac' after bout 1 was higher than that of adults, this cannot be accounted for by their lower SR. We found a negative but very weak association between SR and sweat $\mathrm{Lac}^{-}(\mathrm{P}>0.05, \mathrm{r}=-0.27$, for all subjects). Such a relationship is not consistent since some investigators have reported an inverse correlation $(7,8,24)$, while studies using single sweat glands have shown a significant positive correlation (14), or none at all (13).

It is unclear why children have higher sweat $\mathrm{Lac}^{-}$at the beginning of exercise. One possibility is that the energy required for the onset of sweating is higher than that required to maintain sweating. The higher sweat $\mathrm{Lac}^{-}$ in children at the start of exercise may be due to their higher sweating threshold $(25,26)$. Timing for sweat collection was the same for all subjects and was set according to exercise duration, which may not necessarily match sweating duration. This time lag could be responsible for the higher sweat $\mathrm{Lac}^{-}$at the start of exercise.

It is difficult to state whether the sweat glands of children respond with a greater glycolytic rate at the start of exercise. Sweat $\mathrm{Lac}^{-}$ may not be an accurate index of glycolytic rate of the sweat gland since some Lac', in conjunction with other ions or in exchange with $\mathrm{H}^{+}$, is reabsorbed in the sweat duct $(14,27)$.

A consistent finding of the present study was that Lac- dropped with exercise duration, which is in agreement with other studies in which subjects cycled at constant work rates $(7,11,18,28,29)$. The drop in sweat Lac could be due to the fact that, besides glycolysis, the sweat gland uses oxygen (oxidative phosphorylation) as a substrate for sweating $(4,30)$. At the start of exercise, the vasoconstrictive effect of epinephrine release and reduced oxygen supply to the skin may cause the sweat glands to rely more on anaerobic glycolysis and produce more $\mathrm{Lac}^{-}$. As exercise continues, especially in a warm environment, more blood is shunted to the skin, thus allowing the sweat glands to work more aerobically. 
Sweat $\mathrm{NH}_{3}$ has rarely been studied during exercise. In the present study, the men's average sweat $\mathrm{NH}_{3}(3.3 \mathrm{mM})$ was somewhat higher than that found when men cycled at $40 \%(2.1$ $\mathrm{mM})$, but much lower than that obtained at a higher exercise intensity $(7.1 \mathrm{mM}$ at $80 \%$ $\mathrm{VO}_{2 \max }$ ) (6). This further indicates that sweat $\mathrm{NH}_{3}$ increases with exercise intensity.

As expected, children had a higher sweat $\mathrm{NH}_{3}$ in the first bout, and this can reflect a mechanism for avoiding further decrease in sweat $\mathrm{pH} . \mathrm{NH}_{3}$ diffusion is facilitated by an increased $\mathrm{pH}$ gradient between compartments. $\mathrm{NH}_{3}$, as a base, diffuses from the extracellular space (higher $\mathrm{pH}$ ) to the sweat gland duct (lower $\mathrm{pH}$ ) where, once protonated to $\mathrm{NH}_{4}{ }^{+}$, it becomes poorly diffusible $(1,5)$. Indeed, the children in the present study had a lower sweat $\mathrm{pH}$ than adults (5.2 vs 6.1 for bout 1; 5.3 vs 6.7 for bout 2) and, at least at the end of bout 2, they tended to have a higher blood $\mathrm{pH}$ (Table 5). To support this hypothesis, we found a significant and positive correlation between sweat $\mathrm{NH}_{3}$ and $\mathrm{H}^{+}$for all the subjects combined $(\mathrm{r}=$ $0.56)$, in agreement with other studies $(5,31)$.

Although some sweat $\mathrm{NH}_{3}$ may originate from plasma, it is unlikely that the higher sweat $\mathrm{NH}_{3}$ of children in this study was a reflection of their greater plasma $\mathrm{NH}_{3}$. At rest, plasma $\mathrm{NH}_{3}$ in children is similar to that of adults (32) and, in response to exercise (treadmill $\mathrm{VO}_{2 \max }$ test), the magnitude of its increase may even be higher in adults than in children (33).

The mechanisms involved in sweat acidification are not known. It was suggested that the duct acidifies the precursor sweat by reabsorbing $\mathrm{HCO}_{3}{ }^{-}$and/or secreting $\mathrm{H}^{+}$in exchange of $\mathrm{Na}^{+}(34,35)$. In the present study, overall sweat $\mathrm{Na}^{+}$was inversely correlated with sweat $\mathrm{H}^{+}(\mathrm{r}=-0.45, \mathrm{P}<0.05)$, but $\mathrm{r}$ values were greater in children than in adults $(-0.43 v s-0.29)$. This indicates that lower sweat $\mathrm{pH}$ in children may be associated with their greater $\mathrm{Na}^{+}$reabsorption.

The average sweat SID $(7 \mathrm{mM})$ in the present study was much lower than that of plasma $(37.6 \mathrm{mM})$. Our values are close to those already reported in men as "residual ions" (14), even though our calculations included ammonia. We did not find a strong inverse correlation between sweat $\mathrm{H}^{+}$and sweat $\operatorname{SID}(r=0.1)$. This is probably due to a lower and small range of sweat (SID). Besides SID, the $\mathrm{H}^{+}$(or acid-base status) of a solution depends on two other variables: $\mathrm{PCO}_{2}$ and weak anions (mostly proteins). In fact, when SID is around zero, very small changes in $\mathrm{PCO}_{2}$ may cause a big change in $\mathrm{pH}$ (and $\mathrm{H}^{+}$) (36). On the other hand, proteins do not affect sweat $\mathrm{H}^{+}$ because of their low concentration in sweat (2 $\mathrm{mg} / \mathrm{dL}$ vs $7 \mathrm{~g} / \mathrm{dL}$ in blood) (1).

Our finding that blood $\mathrm{pH}$ did not change over time in men is in agreement with a study that used a similar exercise/heat protocol (37). Although in children an increase in blood $\mathrm{pH}$ achieved significance, the $\mathrm{pH}$ changes among groups were similar. This is somewhat divergent from high intensity exercise in which a fall in blood $\mathrm{pH}$ is considerably greater in adults than in children (38). The overall decrease in blood $\mathrm{pH}$ in the present study may be due to increased ventilation (as shown by the $\mathrm{PCO}_{2}$ decrease) and increased skin blood flow (perfusion), both promoted by increased body temperature (39).

We have shown that children present a higher sweat $\mathrm{Lac}^{-}$and $\mathrm{NH}_{3}$ compared to adults during the first $20 \mathrm{~min}$ of exercise in the heat. Within one hour of exercise, the overall sweat losses of $\mathrm{Lac}^{-}$and $\mathrm{NH}_{3}$ corrected per kg body mass were similar among groups. These results are representative of an exercise plus heat stress that was too low to induce fatigue or blood acidosis. The extent to which such a pattern will persist during exercise-induced acidosis has yet to be determined.

\section{Acknowledgments}

We would like to thank Márcia dos Santos Dornelles and Dr. Álvaro Reischak de Oliveira for technical assistance. 


\section{References}

1. Sato K, Kang WH, Saga K, Sato KT. Biology of sweat glands and their disorders. I. Normal sweat gland function. J Am Acad Dermatol 1989; 20: 537-563.

2. Gordon RS Jr, Thompson RH, Muenzer J, Thrasher D. Sweat lactate in man is derived from blood glucose. J Appl Physiol 1971; 31: 713-716.

3. Sato K, Dobson RL. Glucose metabolism of the isolated eccrine sweat gland. II. The relation between glucose metabolism and sodium transport. J Clin Invest 1973; 52: 2166-2174.

4. Sato K. The physiology, pharmacology, and biochemistry of the eccrine sweat gland. Rev Physiol Biochem Pharmacol 1977; 79: 51131.

5. Brusilow SW, Gordes EH. Ammonia secretion in sweat. Am J Physiol 1968; 214: 513-517.

6. Czarnowski D, Gorski J. Sweat ammonia excretion during submaximal cycling exercise. J Appl Physiol 1991; 70: 371-374.

7. Falk B, Bar-Or O, MacDougall JD, McGillis L, Calvert R, Meyer F. Sweat lactate in exercising children and adolescents of varying physical maturity. J Appl Physiol 1991; 71: 1735-1740.

8. Lamont LS. Sweat lactate secretion during exercise in relation to women's aerobic capacity. J Appl Physiol 1987; 62: 194-198.

9. Buono MJ, Sjoholm NT. Effect of physical training on peripheral sweat production. J Appl Physiol 1988; 65: 811-814.

10. Meyer F, Bar-Or O, MacDougall D, Heigenhauser GJ. Sweat electrolyte loss during exercise in the heat: effects of gender and maturation. Med Sci Sports Exerc 1992; 24: 776-781.

11. Green JM, Bishop PA, Muir IH, McLester JR Jr, Heath HE. Effects of high and low blood lactate concentrations on sweat lactate response. Int J Sports Med 2000; 21: 556-560.

12. Yuan $\mathrm{Y}$, Chan KM. A review of the literature on the application of blood ammonia measurement in sports science. Res $Q$ Exerc Sport 2000; 71: 145-151.

13. Kaiser D, Songo-Williams R, Drack E. Hydrogen ion and electrolyte excretion of the single human sweat gland. Pflugers Arch 1974; 349: 63-72.

14. Bijman J, Quinton PM. Lactate and bicarbonate uptake in the sweat duct of cystic fibrosis and normal subjects. Pediatr Res 1987; 21: 79-82.

15. DuBois D, DuBois EF. Clinical calorimetry: a formula to estimate the approximate surface area if height and weight be known. Arch Intern Med 1916; 17: 863-871.

16. Mitchell JW, Nadel ER, Stolwijk JA. Respiratory weight losses during exercise. J Appl Physiol 1972; 32: 474-476.

17. Harrison $\mathrm{MH}$. Effects of thermal stress and exercise on blood volume in humans. Physiol Rev 1985; 65: 149-209.

18. Fellmann N, Grizard G, Coudert J. Human frontal sweat rate and lactate concentration during heat exposure and exercise. $J \mathrm{Appl}$ Physiol 1983; 54: 355-360.

19. Calvert R, Bar-Or O, Meyer F, Falk B, Blimkie CJ. A modified, disposable and reliable sweat collection device for use in adults and children during exercise in the heat. Med Sci Sports Exerc 2006; 22: S89 (Abstract).

20. Sato K, Sato F. Methods for studying eccrine sweat gland function in vivo and in vitro. Methods Enzymol 1990; 192: 583-599.

21. Lemon PW, Yarasheski KE, Dolny DG. Validity/reliability of sweat analysis by whole-body washdown vs regional collections. J Appl Physiol 1986; 61: 1967-1971.

22. Shirreffs SM, Maughan RJ. Whole body sweat collection in humans: an improved method with preliminary data on electrolyte content. $J$ Appl Physiol 1997; 82: 336-341.

23. Patterson MJ, Galloway SD, Nimmo MA. Variations in regional sweat composition in normal human males. Exp Physiol 2000; 85: 869-875.

24. Fellmann N, Labbe A, Gachon AM, Coudert J. Thermal sweat lactate in cystic fibrosis and in normal children. Eur J Appl Physiol Occup Physiol 1985; 54: 511-516.

25. Araki T, Toda Y, Matsushita K, Tsujino A. Age differences in sweating during muscular exercise. Jpn J Phys Fitness Sports Med 1979; 28: 239-248.

26. Wagner JA, Robinson S, Tzankoff SP, Marino RP. Heat tolerance and acclimatization to work in the heat in relation to age. $J \mathrm{Appl}$ Physiol 1972; 33: 616-622.

27. Bijman J, Quinton PM. Influence of abnormal Cl- impermeability on sweating in cystic fibrosis. Am J Physiol 1984; 247: C3-C9.

28. Green JM, Pritchett RC, Tucker DC, Crews TR, McLester JR. Sweat lactate response during cycling at 30 degrees $\mathrm{C}$ and 18 degrees $\mathrm{C}$ WBGT. J Sports Sci 2004; 22: 321-327.

29. Green JM, Pritchett RC, Crews TR, McLester JR Jr, Tucker DC. Sweat lactate response between males with high and low aerobic fitness. Eur J Appl Physiol 2004; 91: 1-6.

30. Fellmann N, Fabry R, Coudert J. Calf sweat lactate in peripheral arterial occlusive disease. Am J Physiol 1989; 257: H395-H398.

31. Morimoto $\mathrm{T}$, Johnson RE. Ammonia and the regulation of acidity in human eccrine sweat. Nature 1967; 216: 813-814.

32. Colombo JP, Peheim E, Kretschmer R, Dauwalder H, Sidiropoulos D. Plasma ammonia concentrations in newborns and children. Clin Chim Acta 1984; 138: 283-291.

33. Nazar K, Dobrzynski B, Lewicki R. Relationship between plasma ammonia and blood lactate concentrations after maximal treadmill exercise in circumpubertal girls and boys. Eur J Appl Physiol Occup Physiol 1992; 65: 246-250.

34. Quinton PM. Suggestion of an abnormal anion exchange mechanism in sweat glands of cystic fibrosis patients. Pediatr Res 1982; 16 : 533-537.

35. Quinton PM. Sweating and its disorders. Annu Rev Med 1983; 34 429-452.

36. Stewart PA. Modern quantitative acid-base chemistry. Can J Physiol Pharmacol 1983; 61: 1444-1461.

37. Sawka MN, Knowlton RG, Glaser RM. Body temperature, respiration, and acid-base equilibrium during prolonged running. Med $\mathrm{Sci}$ Sports Exerc 1980; 12: 370-374.

38. Zanconato S, Buchthal S, Barstow TJ, Cooper DM. ${ }^{31} \mathrm{P}$-magnetic resonance spectroscopy of leg muscle metabolism during exercise in children and adults. J Appl Physiol 1993; 74: 2214-2218.

39. Senay LC Jr, Christensen ML. Respiration of dehydrating men undergoing heat stress. J Appl Physiol 1967; 22: 282-286. 